\title{
Interactive Effects of Nitrogen and Row Spacing on Growth and Yield of Cotton Varieties
}

\author{
Ramzan Ali Alitabar ${ }^{1}$, R. Salimbeck ${ }^{1}$, O. Alishah ${ }^{2} \&$ Seyed Abbas-Ali Andarkhor ${ }^{1}$ \\ ${ }^{1}$ Department of Agronomy, Tajik Agrarian University, Agricultural and Natural Resources Research Center, \\ Mazandaran, Iran \\ ${ }^{2}$ Breeding Department of Cotton Research Institute, Iran \\ Correspondence: Ramzan Ali Alitabar, Department of Agronomy, Tajik Agrarian University, Agricultural and \\ Natural Resources Research Center, Mazandaran, Iran. E-mail: r_alitabar@yahoo.com
}

Received: January 16, 2012 Accepted: February 9, 2012 Online Published: June 26, 2012

doi:10.5539/ijb.v4n3p124 URL: http://dx.doi.org/10.5539/ijb.v4n3p124

\begin{abstract}
Response of different cultivars of cotton namely Sahel, N200 and Shirpan539 to different levels of row spacing $40 \mathrm{~cm} \times 20 \mathrm{~cm}$ and $80 \mathrm{~cm} \times 20 \mathrm{~cm}$ and $0,75,150$ and $225 \mathrm{~kg} \mathrm{ha}^{-1}$ nitrogen fertilizer was studied at Gharakhil Agricultural research Station, North of Iran in 2010. Different row spacing influenced height and number of boll and different nitrogen levels significantly influenced yield and yield components of cotton. Application of 150 $\mathrm{kg} \cdot \mathrm{ha}^{-1}$ nitrogen fertilizer produced maximum yield, number of boll and maturity coefficient as compared to another nitrogen rates. In level of $225 \mathrm{~kg} \cdot \mathrm{ha}^{-1}$ nitrogen fertilizer we observed maximum height, number of node, weight of boll and number of sympodial branch as compared to the another nitrogen rates. The varieties N200 and Sahel provided maximum yield as compared to Shirpan539.
\end{abstract}

Keywords: cotton, growth, nitrogen, plant spacing, yield, sympodial branch

\section{Introduction}

Cotton is the most valuable major cash crop. The need for cotton products have ensured its survival as one of the world's most widely cultivated crop, despite the stiff competition it faces from man-made fibers. Cotton (Gossypium spp.) is grown in about 76 countries, covering more than 32 million hectares of land (Saranga et al., 2001). Cotton has been economically cultivating in Iran since 85 years. Out of total 30 province, cotton is grown in 17 provinces and 108000 ha area was covered by it (http:// www.Unicot.Org/en-News.html).

Cotton (Gossypium hirsutumL.) is usually planted in rows spaced 76 to $80 \mathrm{~cm}$ apart andthese row spacing have been utilized since mules and plows were the primary source of farm machinery (Williford, 1992). As farm equipment evolved, this row spacing remained a common practice in order to accommodate tractors and cultivators. In addition, there were few effective herbicides available in earlier cotton production systems that could be applied topically for weed control so cultivation was a necessary practice. Planting cotton in narrow-row patterns is now feasible due to seed technology and herbicide-resistant cotton varieties (Culpepper \& York, 2000).

Advances in planter technology allowing precise seed simulation and placement and improving finger strippers for harvest have led to improved stand establishment and harvest efficiency.

Nichols et al. (2004) stated that plant height and number of sympodial branch, total nodes, and total bolls per plant were reduced in cotton grown in ultra-narrow row spacing. In most cases, cotton grown in ultra- narrow rows. had lint yields equal to or higher than those attained in the 101-cm spacing. According to Mcfarland et al. (2002), the ultra-narrow row spacing is $19-38 \mathrm{~cm}$.

Nitrogen is generally considered to be a limiting factor for the growth, yield and radiation use efficiency of various cotton cultivars (Nicholos et al., 2004). Its deficiency reduces vegetative and reproductive growth and reducing yield due to leaf senescence (Tewolde \& Fernandez, 1997). On the other hand, high $\mathrm{N}$ availability may shift the balance between vegetative and reproductive growth toward excessive vegetative development, thus delaying crop maturity and reducing seed cotton yield (Howard et al., 2001). Higher doses of N lead to more vegetative growth and causes delay in maturity and ultimately reduction in the crop yield (Howard et al., 2001). Effect of excess doses of $\mathrm{N}$ application on growth, yield and fruiting are less apparent than its deficiency 
(Jackson \& Gerik, 1990). Lint yield response to increased $\mathrm{N}$ doses follows a diminishing return trend but total dry matter, accumulated radiation and its efficiency show linear response (Girme et al., 1998). It is well documented that yield of cotton varies among different cultivars. Boquet et al. (1994) found that cotton yield enhanced due to increase in boll weight by the application of nitrogen at various rates. Due to different effects of row spacing and nitrogen levels application on cotton yield associated traits, this study was carried out to determine the suitable row spacings and nitorogen levels for improving yield and yield associated traits in cotton varieties.

\section{Materials and Methods}

\subsection{Field Preparation and Treatments}

Research was conducted during 2010 at the Gharakhil agricultural Research Institute. This station located in Mazandaran province, North of Iran, at N $56.18^{\circ}$ and E $36.08^{\circ}$. According of meteorological research station, the average precipitation, maximum and minimum temperature during 10 years were $742 \mathrm{~mm}, 30.6$ and $5{ }^{\circ} \mathrm{C}$ respectively.

Field preparation in the fall consisted of disking, sub soiling, and bedding. In the spring, beds were reduced to approximately $8 \mathrm{~cm}$ with a reel and harrow conditioner. These low beds were suitable for irrigation and planting.

The soil of experimental sites was clay loam (fine mixed, calcareous, thermic fluvaquents). Analysis at a soil depth of $30 \mathrm{~cm}$ indicates that it contains $3.55 \%$ organic matter, $2.06 \%$ organic carbohydrate, 0.172 total N, 19.5 $\mathrm{mg} \mathrm{kg}{ }^{-1} \mathrm{p}$ and $195 \mathrm{mg} \mathrm{kg}^{-1} \mathrm{~K}$ and $\mathrm{pH} 7.5$ at Gharakhil site. $\mathrm{K}_{2} \mathrm{O} @ 150 \mathrm{~kg} \mathrm{ha}^{-1}$ as sulphate of potash were applied as a basal dose in all treatments. The climate sites is temperate. Cotton varieties Sahel, N200 and Shirpan were planted on May 12, 2009 by hand. Row spacing in this experiment was $40 \mathrm{~cm} \times 20 \mathrm{~cm}$ and $80 \mathrm{~cm} \times 20 \mathrm{~cm}$ and four levels of $0,75,150$ and $225 \mathrm{~kg} \mathrm{ha}^{-1}$ nitrogen fertilizerwere applied half the nitrogen as the base and the other half use in two equal splits, at 1 and 2 nd. weeding.

Weed control procedures consisted of pre plant application of Treflan (1.5 lit.ha $\left.{ }^{-1}\right)$ and hand weeding. Pest control was with Index acarb E.C.15 $\left(250 \mathrm{mmha}^{-1}\right)$ was applied for controlling Helicoverpa armigera.

\subsection{Data Collection}

Ten plants from each plot were selected at random to record number of monopodial and sympodial branches plant $^{-1}$, number and weight of matured bolls plant ${ }^{-1}$ and plant height at maturity. The seed cotton was handpicked and weighed for plot yields and then calculated in $\mathrm{kg} \mathrm{ha}^{-1}$.

\subsection{Experimental Design and Statistical Analysis}

The experimental design was randomized complete block with split splits structure having four replications and plot size of $7.0 \mathrm{~m} \times 3.2 \mathrm{~m}$. The data were analyzed at the $5 \%$ level by using Duncan's Multiple Range Test (Duncan, 1970) to compare the treatment means.

\section{Results and Discussion}

Analysis of variance carried out for studied traits are present in Table 1. This analysis showed that effect of variety (factor A) was significant on some traits such as number of boll and maturity coefficient at $1 \%$ and yield and number of sympodial branches at $5 \%$ level those showed significant statistical difference between varieties, which is indicating the significant genetic differences of the genotypes.

This experiment showed that effect of row spacing (factor B) was significant on weight of boll and maturity coefficient (\%) at $1 \%$ and number of nodes at $5 \%$ level. The interaction of Ax B also was not significant for all traits. These results showed that the trend variation of the traits in the genotypes were similar in different row spacing.

The effect of nitrogen fertilizer (factor C) was significant (at 1\% level) on all studied traits. The interaction of variety $\mathrm{x}$ nitrogen fertilizer and row spacing $\mathrm{x}$ nitrogen fertilizer were not significant on all traits. In this study we observed that interaction of variety $\mathrm{x}$ row spacing $\mathrm{x}$ nitrogen fertilizer was significant only on number of boll at $5 \%$ level with this experiment we concluded that nitrogen had significant effects on all of traits. The results also indicated that nitrogen had significant effects had on all of traits. 
Table 1. Variance analysis (ANOVA) of different traits

\begin{tabular}{|c|c|c|c|c|c|c|c|c|}
\hline \multicolumn{9}{|c|}{ Mean squares } \\
\hline S.O.V. & df & Yield(kg.ha $\left.{ }^{-1}\right)$ & Height(cm) & $\begin{array}{l}\text { Number } \\
\text { of Node }\end{array}$ & $\begin{array}{l}\text { Number of } \\
\text { Boll }\end{array}$ & $\begin{array}{l}\text { Weight } \\
\text { of } \\
\text { Boll(gr) }\end{array}$ & $\begin{array}{c}\text { Maturity } \\
\text { Coefficient } \\
(\%)\end{array}$ & $\begin{array}{c}\text { Number } \\
\text { of } \\
\text { Sympodial } \\
\text { Branch }\end{array}$ \\
\hline Factor A & 2 & $1665850.593^{*}$ & $2655.148^{\mathrm{ns}}$ & $40.512^{\mathrm{ns}}$ & $334.060^{\pi *}$ & $4.481^{\mathrm{ns}}$ & $2254.903^{\text {*न }}$ & $61.928^{*}$ \\
\hline Error & 6 & 241132.872 & 571.166 & 17.428 & 26.061 & 0.934 & 112.667 & 11.307 \\
\hline Factor B & 1 & $34379.911^{\text {ns }}$ & $654.536^{\mathrm{ns}}$ & $42.480^{*}$ & $153.596^{\mathrm{ns}}$ & $3.110^{* *}$ & $451.837^{* *}$ & $4.365^{\mathrm{ns}}$ \\
\hline $\mathrm{AB}$ & 2 & $82086.836^{\text {ns }}$ & $512.243^{\mathrm{ns}}$ & $18.504^{\mathrm{ns}}$ & $11.563^{\mathrm{ns}}$ & $0.402^{\mathrm{ns}}$ & $15.234^{\mathrm{ns}}$ & $0.079^{\mathrm{ns}}$ \\
\hline Error & 9 & 313274.108 & 123.987 & 6.005 & 43.791 & 0.261 & 18.864 & 2.471 \\
\hline Factor C & 3 & $2256167.291^{* *}$ & $3229.200^{* *}$ & $84.774^{* *}$ & $283.626^{* *}$ & $3.254^{* *}$ & $1437.755^{* *}$ & $12.820^{* *}$ \\
\hline $\mathrm{AC}$ & 6 & $117827.043^{\mathrm{ns}}$ & $53.763^{\mathrm{ns}}$ & $1.820^{\mathrm{ns}}$ & $14.084^{\mathrm{ns}}$ & $0.193^{\mathrm{ns}}$ & $8.856^{\text {ns }}$ & $0.773^{\mathrm{ns}}$ \\
\hline $\mathrm{BC}$ & 3 & $160151.392^{\mathrm{ns}}$ & $84.898^{\mathrm{ns}}$ & $1.349^{\mathrm{ns}}$ & $11.146^{\mathrm{ns}}$ & $0.113^{\mathrm{ns}}$ & $37.429^{\mathrm{ns}}$ & $0.148^{\mathrm{ns}}$ \\
\hline $\mathrm{ABC}$ & 6 & $21878.769^{\text {ns }}$ & $41.398^{\mathrm{ns}}$ & $1.529^{\mathrm{ns}}$ & $19.691^{*}$ & $0.247^{\mathrm{ns}}$ & $3.696^{\mathrm{ns}}$ & $0.253^{\text {ns }}$ \\
\hline Error & 54 & 297473.066 & 93.741 & 1.525 & 8.322 & 0.306 & 90.257 & 2.827 \\
\hline
\end{tabular}

Factor $\mathrm{A}=$ Variety, Factor $\mathrm{B}=$ Row Spacing, Factor $\mathrm{C}=$ Nitrogen Fertilizer

${ }^{\mathrm{ns}}=$ Non significant, $*$ and $* *=$ difference significant at the 0.05 and 0.01 levels.

\subsection{Yield $\left(\mathrm{kg} \mathrm{ha}^{-1}\right)$}

Data pertaining to yield of cotton per hectare in table 2 indicated that varieties had significant effect on the yield per hectare. The data revealed that significantly the maximum yield $\left(3027.24 \mathrm{~kg} . \mathrm{ha}^{-1}\right)$ was recorded in variety N200 had not significant difference with Sahel. Yield is the combined effect of various yield components under particular environmental conditions. These results are supported by the findingsmade by Khan et al. (1989), Hofs et al. (2006) and Copur (2006).Average yield were not significantly different in row spacing. These results are in contradiction with the findings of Buehring, N. and R. Dobbs (2000). Data indicated that nitrogen had significant effect on the yield per hectare. Highest yield per hectare $(3262.89 \mathrm{~kg})$ was recorded for nitrogen fertilizerat a rate of $150 \mathrm{~kg} \cdot \mathrm{ha}^{-1}$ which differed significantly higher than 0 and $75 \mathrm{~kg} \cdot \mathrm{ha}^{-1}$ nitrogen fertilizer. While minimum $\left(2534.31 \mathrm{~kg}\right.$ ) yield was recorded in $0 \mathrm{~kg} \mathrm{ha}^{-1}$. These results are supported byClawson et al. (2006) who reported that nitrogen influenced seed cotton yield per hectare and decrease in yield per hectare was recorded when nitrogen was applied above the optimum level.

Table 2. Effect of cotton varieties, row spacing and nitrogen rates on yield and yield components

\begin{tabular}{|c|c|c|c|c|c|c|c|}
\hline S.O.V & $\begin{array}{c}\text { Yield } \\
\left(\mathrm{kg}^{\left.-h \mathrm{ha}^{-1}\right)}\right.\end{array}$ & $\begin{array}{c}\text { Plant } \\
\text { Height }(\mathrm{cm})\end{array}$ & $\begin{array}{l}\text { Number } \\
\text { of Node }\end{array}$ & $\begin{array}{l}\text { Number } \\
\text { of Boll }\end{array}$ & $\begin{array}{l}\text { Weight } \\
\text { of Boll } \\
\text { per } \\
\text { pant }(g)\end{array}$ & $\begin{array}{c}\text { Maturity } \\
\text { Coefficient } \\
(\%)\end{array}$ & $\begin{array}{c}\text { Number of } \\
\text { Sympodial } \\
\text { Branch }\end{array}$ \\
\hline \multicolumn{8}{|c|}{ Variety(v) } \\
\hline Sahel & $3007.16 \mathrm{a}$ & $113.06 \mathrm{ab}$ & $19.64 \mathrm{a}$ & $13.70 \mathrm{~b}$ & $5.80 \mathrm{a}$ & $52.59 \mathrm{a}$ & $6.77 \mathrm{~b}$ \\
\hline N200 & $3027.24 \mathrm{a}$ & $125.62 \mathrm{a}$ & $21.89 \mathrm{a}$ & $19.23 \mathrm{a}$ & $5.17 \mathrm{~b}$ & $49.96 a$ & $9.55 \mathrm{a}$ \\
\hline Shirpan & $2622.39 b$ & $107.91 \mathrm{~b}$ & $20.77 \mathrm{a}$ & $19.35 \mathrm{a}$ & $5.13 b$ & $36.91 \mathrm{~b}$ & $8.35 \mathrm{ab}$ \\
\hline \multicolumn{8}{|c|}{ Row Spacing(S) } \\
\hline $40 \times 20 \mathrm{~cm}$ & $2904.52 \mathrm{a}$ & $118.14 \mathrm{a}$ & $20.10 \mathrm{~b}$ & $16.16 \mathrm{a}$ & $5.19 b$ & $48.66 \mathrm{a}$ & $8.01 \mathrm{a}$ \\
\hline $80 \times 20 \mathrm{~cm}$ & $2866.67 \mathrm{a}$ & $112.92 \mathrm{a}$ & $21.43 \mathrm{a}$ & $18.69 \mathrm{a}$ & $5.55 \mathrm{a}$ & $44.32 b$ & $8.44 \mathrm{a}$ \\
\hline \multicolumn{8}{|c|}{ Nitrogen Fertilizer(N) } \\
\hline $\mathrm{N}_{1}=0 \mathrm{~kg} \cdot \mathrm{ha}^{-1}$ & $2534.31 \mathrm{c}$ & $101.80 \mathrm{~d}$ & $18.45 \mathrm{~d}$ & $12.91 \mathrm{c}$ & $4.88 \mathrm{c}$ & $38.03 \mathrm{c}$ & $7.46 \mathrm{~b}$ \\
\hline $\mathrm{N}_{2}=75 \mathrm{~kg} \cdot \mathrm{ha}^{-1}$ & $2783.33 b c$ & $112.31 \mathrm{c}$ & $20.34 \mathrm{c}$ & $16.60 \mathrm{~b}$ & $5.31 \mathrm{~b}$ & $46.96 \mathrm{~b}$ & $7.95 \mathrm{~b}$ \\
\hline $\mathrm{N}_{3}=150 \mathrm{~kg} \cdot \mathrm{ha}^{-1}$ & $3262.89 \mathrm{a}$ & $118.49 \mathrm{~b}$ & $21.33 \mathrm{~b}$ & $20.25 \mathrm{a}$ & $5.59 \mathrm{ab}$ & $56.65 \mathrm{a}$ & $8.29 \mathrm{ab}$ \\
\hline $\mathrm{N}_{4}=225 \mathrm{~kg} \cdot \mathrm{ha}^{-1}$ & $2961.86 \mathrm{ab}$ & $129.53 \mathrm{a}$ & $22.94 \mathrm{a}$ & $19.96 \mathrm{a}$ & $5.70 \mathrm{a}$ & $44.31 \mathrm{~b}$ & $9.19 \mathrm{a}$ \\
\hline
\end{tabular}




\subsection{Plant Height $(\mathrm{cm})$}

Varieties showed the significant results in case of height. Statistically same height was recorded in varieties Sahel and Shirpan $(113.06$ and $107.91 \mathrm{~cm})$ against the maximum height $(125.62 \mathrm{~cm})$ in case of variety N200. Difference observed for plant height among cotton varieties can be attributed to variation in genetic makeup of plants. These results are supported by the findings of Anwar et al. (2002) and Copur (2006) who also reported significant differences among cultivars for plant height. The height of plant was did not differ significantly in row spacing. These findings are in agreement with other studies where no effect of row spacing on plant height was recorded (Atwell, 1996; Gerik et al., 1998; Gwathmey, 1996). Plant height is a genetically controlled factor but environmental and nutritional stress may also influence the height of a plant. The data regarding plant height in Table 2 revealed significant differences for plant height among different levels of nitrogen fertilizers.Application of $225 \mathrm{~kg} \cdot \mathrm{ha}^{-1}$ nitrogen fertilizer produced the tallest plants $(129.53 \mathrm{~cm})$. Soomro and Waring (1987) reported significant differences in plant height with different levels of $\mathrm{N}$ application that similar with our finding in this study.

\subsection{Number of Node per Plant}

Data representing the number of node per plant are presented in Table 2 showed no significant differences among varieties. Number of node for Sahel, N200 and Shirpan varieties were 19.64, 21.89 and 20.77 nodes per plant respectively. Number of node per plant in $40 \mathrm{~cm} \times 20 \mathrm{~cm}$ and $80 \mathrm{~cm} \times 20 \mathrm{~cm}$ were 20.10 and 21.43 node in per plant. These responses are consistent with previous studies that reported narrow row spacing cause decreased on number of node per plants (Jost \& Cothren, 2000; Clawson et al., 2006 ).Maximum number of node (22.94) was recorded where nitrogen was applied at the rate of $225 \mathrm{~kg} \mathrm{ha}^{-1}$ which were statistically different with the another rate of nitrogen fertilizer. The findings from our study agree with those of Clawson et al. (2006) who reported Main stem nodes plant ${ }^{-1}$ were significantly increased with higher $\mathrm{N}$ rates.

\subsection{Number of Bolls per Plant}

The data on number of bolls per plant presented in Table 2 exhibited significant differences among the varieties. Maximum number of boll per plant was observed in variety Shirpan (19.35). The varieties Shirpan (19.35) and N200 (19.23) produced statistically same number of bolls per plant. The minimum number of bolls per plant was found in variety Sahel (13.70). The differences among cultivars for number of bolls per plant might have been due to the difference in genetic potential of the cultivars. The significant differences among varieties for number of bolls per plant had also been reported by Copur (2006) and Ehsan, et al. (2008).Despite of theincreasednumber ofbollsper plant in conventional row spacing this increase was not significantly different than narrow row spacing.Application of $150 \mathrm{~kg} \cdot \mathrm{ha}^{-1}$ nitrogen fertilizerproduced the highest number of bolls per plant (20.57), which was statistically at par with the application rate of $225 \mathrm{~kg} \mathrm{ha}^{-1}$. Similar results also reported by Boquet et al. (1993).

\subsection{Average Boll Weight per Plant (g)}

Data representing the average boll weight are presented in Table 2 showed significant differences among varieties. Average boll weight for varieties Sahel, N200 and Shirpan were 5.80, 5.17 and 5.13 gr respectively. Statistically same average boll weight was recorded in varieties N200andShirpan against the maximumaverage boll weight in case of variety Sahel.The significant differences among varieties for average boll weight had also been reported by Hofs et al. (2006) that was coordinate with finding in this experiment. Average boll weights were significantly different in row spacing. Maximum average boll weight $(5.55 \mathrm{~g})$ was recorded in $80 \mathrm{~cm} \times 20$ $\mathrm{cm}$ row spacing. These results are in consonance with the findings of Hussain et al. (2000) who reported that wider spacing increased average boll weight. The average boll weight was $4.88,5.31,5.59$ and $5.70 \mathrm{~g}$ in 0,75 , 150 and $225 \mathrm{~kg} \mathrm{ha}^{-1}$ respectively. Maximum boll weight observed in $225 \mathrm{~kg} \mathrm{~N} \mathrm{ha}^{-1}(5.70 \mathrm{~g})$, there was no significant difference in boll weight between 225 and $150 \mathrm{~kg} \mathrm{~N}^{-1}$. Nitrogen at the rate of $150 \mathrm{~kg} \mathrm{ha}^{-1}$ was statistically at par with the application rate of $75 \mathrm{~kg} \mathrm{~N} \mathrm{ha}^{-1}$. The findings from our study agree with those of Sawan et al. (2006); who recorded increase in boll weight by increasing $\mathrm{N}$ rate from 95 to $143 \mathrm{~kg} \mathrm{ha}^{-1}$.

\subsection{Maturity Coefficient (\%)}

Data representing the maturity coefficient are presented in Table 2 showed significant differences among varieties. Maturity coefficient for varieties Sahel, N200 and Shirpan were $52.59 \%, 49.96 \%$ and $36.91 \%$ respectively. Statistically same maturity coefficient (\%) was recorded in varieties Sahel and N200 against the minimum maturity coefficient in case of variety Shirpan. Average maturity coefficient (\%) was significantly different in row spacing. Maximum maturity coefficient $(48.66 \%)$ was recorded in $40 \times 20 \mathrm{~cm}$ row spacing. In previous research, the occurrence of early maturity in narrow row spacing relative to conventional row spacing 
has been somewhat inconsistent. Jost and Cothren (2001) found evidence of substantially earlier maturity for narrow row spacing than for conventional row spacing treatments in the initial study year, but did not find treatment differences in the following year. Galanopoulou - Sendouka et al. (1980) found that narrow row spacing treatments were significantly earlier in mean maturity date than a narrow row spacing treatment within an early planting date in one study year. The maturity coefficient was $38.03 \%, 46.96 \%, 56.65 \%$ and $44.31 \%$ in 0 , 75,150 and $225 \mathrm{~kg} \mathrm{ha}^{-1}$ in nitrogen fertilizers respectively. In this experiment it_-1was observed that in $225 \mathrm{~kg} \mathrm{ha}^{-1}$ nitrogen fertilizer maturity coefficient had significant difference with $150 \mathrm{~kg}$ ha nitrogen fertilizer. The findings from our study agree with McConnell et al. (1996) who recorded decrease maturity coefficient by increasing $\mathrm{N}$ rate.

\subsection{Number of Sympodial Branches per Plant}

Data representing number of sympodial branches per plant are presented in Table 2. There was significant effect between Varieties for Number of sympodial branch. Maximum number of sympodial branches plant ${ }^{-1}(9.55)$ was recorded in variety N200. Plant spacing had non-significant effect on the number of sympodial branches per plant. Statistically the maximum number of sympodial branches per plant (8.44) was recorded in conventional row spacing $(80 \mathrm{~cm} \times 20 \mathrm{~cm})$ which was statistically at par with ultra-narrow row spacing $(40 \mathrm{~cm} \times 20 \mathrm{~cm})$. Ghajari and Ghaderi (2006) who reported non-significant effect of row spacing on number of sympodial branches. In this study observed increased nitrogen levels led to increased number of sympodial branches in per plant. Maximum number of sympodial branches plant ${ }^{-1}(9.19)$ was recorded in $225 \mathrm{~kg}^{-h a^{-1}}$ nitrogen fertilizer and Control $\left(0 \mathrm{~kg} \mathrm{ha}^{-1}\right)$ gave the lowest number of sympodial branches plant ${ }^{-1}$ (7.46). These results are in contradiction with the findings of Kumbhar et al. (2008) who reported more number of sympodial branches per plant in upper levels of nitrogen.

\section{Conclusion}

It may be concluded from this study that application rate of $150 \mathrm{~kg} \cdot \mathrm{ha}^{-1}$ nitrogen fertilizer and row spacing $40 \mathrm{~cm}$ x $20 \mathrm{~cm}$ produced optimum yield per hectare. The results also showed that in $40 \mathrm{~cm}$ x $20 \mathrm{~cm}$ and in rate of 150 $\mathrm{kg} . \mathrm{ha}^{-1}$ nitrogen fertilizer had higher maturity coefficient. Therefore, it is recommended that system arrangement of $80 \mathrm{~cm} \times 20 \mathrm{~cm}$ is most suitable for achieving higher yield of cotton under agro-ecological conditions in 2010 of Gharakhil station in north of Iran, especially for Sahel variety.

\section{References}

Anwar, A. M., Gill, M. I., Muhammad, D., \& Afzal, M. N. (2002). Evaluation of cotton varietiesat different doses of nitrogen fertilizer. The Pak. Cottons, 46(1-4), 35-41.

Atwell, S. D., R. Perkins, B. Guice, W. Stewart, J. Harden, \& T. Odeneal. (1996). "Essential steps to successful ultra-narrow row on cotton production," in Proceedings of the Beltwide Cotton Conference, pp. 1210-1211, National Cotton Council of America, Nashville, Tenn, USA.

Boquet, D. J., Moser, E. B., \& Breitenbeck. G. A. (1994). Boll weight and with in plant yield distribution in field grown given different levels of nitrogen. Agron. J., 86(10), 20-26. http://dx.doi.org/10.2134/agronj1994.00021962008600010005x

Boquet, D. J., Moser, E. B., \& Breitenbeck, G. A. (1993). Nitrogen effects on boll production of field grown cotton, Agron. J., 85(1), 34-39. http://dx.doi.org/10.2134/agronj1993.00021962008500010007x

Buehring, N., \& Dobbs. R. (2000). Cotton plant population effect on growth and yield. p. 660-661. In P. Dugger and D. Richter (ed.) Proc. Belt wide Cotton Conf., San Antonio, TX. 4-8 Jan. 2000. National Cotton Council, Memphis, TN.

Clawson, E. L., Cothren, J. T., \& Blouin, D. C. (2006). Nitrogen fertilizationandyield of cotton in ultra-narrow and conventional row spacings. Agron. J., 98, 72-79. http://dx.doi.org/10.2134/agronj2005.0033

Copur, O. (2006). Determination of yield and yieldcomponents of some cotton cultivars in semi-arid conditions. Pak. J Biol. Sci., 9(14), 2572-2578. http://dx.doi.org/10.3923/pjbs.2006.2572.2578

Culpepper, A. S., \& York. A. C. (2000). Weed management in ultra-narrow row cotton (Gossypiumhirsutum).

Duncan, D. B. (1970). Multiple rangesand multiple F. Test. Biometrics, 11, 1-42. http://dx.doi.org/10.2307/3001478

Ehsan, F., Ali, A., Nadeem, M. A., Tahir, M., \& Majeed. A. (2008). Comparative Yield Performance of New Cultivars of Cotton (GossypiumhirsutumL.). Pakistan Journal of life social, 6(1), 1-3.

Galanopoulou-Sendouka, S., A. Sficas, G., Fotiadis, N. A., Gagianas, A. A., \& Gerakis. P. A. (1980). Effect of population density, planting date, and genotype on plant growth and development of cotton. Agron. J., 72, 
347-353. http://dx.doi.org/10.2134/agronj1980.00021962007200020022x

Gerik, T. J., Lemon, R. G., Faver, K. L., Hoelewyn, T. A., \& Jung man. M. (1998). Performance of ultra-narrow row cotton in central Texas. p. 1406-1408. In P. Dugger and D. Richter (ed.) Proc. Beltwide Cotton Conf., New Orleans, LA. 6-10 Jan. 1998. NationalCotton Council, Memphis, TN.

Ghajari, A., \& Akramghaderi. F. (2006). Influence of Row Spacing and Population Density onyield and yield components of three cotton cultivars in Gorgan Journal of Agricultural Science Islamic Azad University.

Girme, K., Teal, R. K., Freeman, K. W., Boman, R. K., \& Raun. W. R. (1998). Cotton lint yield and quality as affected by cultivar and long term applications of N, P and K fertilizers. Proc. Aust. Agron. Conf., 310-318.

Gwathmey, O. W., \& Hayes, R. M. (1996). Ultra-narrow-row systems of no-till cotton production: Research progress in Tennessee. p. 61-67. In Proc. South. Conserv. Tillage Conf. for Sustain. Agric., Jackson, TN. 23-25 July 1996. Tenn. Agric. Exp. Stn. Spec. Publ. 96-07.

Hofs, J. L., Hau, B., \& Marais, D. (2006). Boll distribution patterns in Bt and non-Bt cotton cultivars: I. Study on commercial irrigated farming systems in South Africa. Field Crops Res., 98(2 \& 3), 203-209. http://dx.doi.org/10.1016/j.fcr.2006.01.006

Howard, D. D., Gwathmey, C. O., Essington, M. E., Roberts, R. K., \& Mullen, M. D. (2001). Nitrogen fertilization of no-till cotton on loess-derived soils. Agron. J., 93, 157-163. http://dx.doi.org/10.2134/agronj2001.931157x

Hussain, S., Farid, Z. S., Anwar, M., Gill, M. I., \& Dilbaugh, M. (2000). Effect of plant density and nitrogen on yield of seed cotton of CIM-473. Sarhad J. Agric., 16.

Jackson, B. S., \& Gerik, T. J. (1990). Boll shedding and boll load in nitrogen stressed cotton at Texas. Agron.J., 82(3), 483-488.

Jost, P. H., \& Cothren, J. T. (2000). Growth and yield comparisons of cotton planted in conventional and ultra-narrow row spacings. Crop Science, 40(2), 430-435.

Jost, P. H., \& Cothren, J. T. (2001). Phenotypic alterations and crop maturity differences in ultra-narrow row and $\begin{array}{lllll}\text { conventionally spaced cotton. Crop } & \text { Science, } & \text { 41(4), }\end{array}$ http://dx.doi.org/10.2135/cropsci2001.4141150x

Khan, W. S., Khan, A. A., Naz, A. S., \& Ali, S. (1989). Performance of six Punjab commercialvarieties of GossypiumhirsutumL. Under Faisalabad conditions. The Pak. Cottons, 33(2), 60-65.

Kumbhar, A. M., Buriro, U. A., Junejo, S., Oad, F. C., Jamro, G. H., Kumbhar, B. A., \& Kumbhar, S. A. (2008). Impact of different nitrogen leves on cotton growth, yield and up-take planted in legume rotation. Pak. $J$. Bot., 40(2), 767-778.

McConnell, J. S., Baker, W. H., \& Frizzell, B. S. (1996). Distribution of residual nitrate-N in long term fertilization studies of an alfisol cropped for cotton. J. Environ. Qual., 25, 1389-1394. http://dx.doi.org/10.2134/jeq1996.00472425002500060032x

McFarland, M. L., Lemon, R. G., Mazac, Pigg, F. J., \& Abrameit, A. (2002). Nitrogen requirements in UNR cotton systems. In P. Dugger and D. A. Richter (ed.) Proc. Beltwide Cotton Conf., Atlanta, GA. 8-12. National Cotton Council, Memphis, TN.

Nicholos, S. P., Snipes, C. E., \& Jones, M. A. (2004). Cotton growth, lint yield, and fiber quality as affected by row spacing and cultivar. J. Cotton Sci., 8, 1-12.

Saranga, Y., Menz, M., Jiang, C. X., Robert, J. W., Yakir, D., \& Andrew, H. P. (2001). Genomic dissection of genotype $\mathrm{x}$ environment interactions conferring adaptation of cotton to arid conditions. Genome Res., 11, 1988-1995. http://dx.doi.org/10.1101/gr.157201

Sawan, Z. M., Mahmoud, M. H., \& El-Guibali, A. H. (2006). Response of yield, yield components,and fiber properties of Egyptian cotton (GossypiumbarbadenseL.) to nitrogen fertilization and foliar- applied potassium and mepiquate chloride. The J. Cotton Science, 10, 224-234.

Soomro, A. W., \& Waring, S. A. (1987). Effect of temporary flooding and N nutrition on cotton growth in soils with different organic matter levels. Australian J. Agri. Res., 38, 91-9. http://dx.doi.org/10.1071/AR9870091

Tewolde, H., \& Fernandez, C. J. (1997). Vegetative and reproductive dry weight inhibition in nitrogen and $\begin{array}{llllll}\text { phosphorus-deficient Pima cotton. J. } & \text { Plant } & \text { Nutr., 20, }\end{array}$ http://dx.doi.org/10.1080/01904169709365245

Williford, J. R. (1992). Production of cotton on narrow row spacing. Trans. ASAE, 35, 1109-1112. 